\title{
Medicinal and Nutritional Wonders of Miracle Moringa oleifera Lam.: Another Look
}

\author{
Raji Sundararajan ${ }^{1, *}$, Edet Love Mendie ${ }^{2}$, Lakshya Mittal ${ }^{1}$, Gowrisree Varadarajan ${ }^{3}$, Ignacio G \\ Camarillo $^{4}$, Hemalatha Srinivasan ${ }^{2}$
}

${ }^{1}$ School of Engineering Technology, Purdue University, Rm 187, Knoy hall of Technology, West Lafayette, IN 47907, USA.

${ }^{2}$ School of Life Sciences, B.S. Abdur Rahman Crescent Engineering College, Vandalur, Chennai, INDIA.

${ }^{3}$ Divison of High Voltage Engineering, Dept. of Electrical and Electronics Engineering, College of Engineering,

Anna University, Guindy, INDIA.

${ }^{4}$ Department of Biological Sciences, Purdue University, West Lafayette, IN 47907, USA.

\begin{abstract}
Background: Frequently described by Bogar and other greatest sithars, Moringa oleifera Lam (Moringa was derived from the Tamil word murungai)), is popular for its medicinal and nutritional values and benefits. Rich with many nutrients, it is useful to prevent and/ or cure diverse kinds of ailments. Methods: Available literature in Google, and other search engines, and gene interaction details from Gencards.org, etc. were used. Results: The various diverse biological and pharmacological activities of Moringa oleifera Lam. (Moringa) include virility, antioxidant, anti-inflammatory, anticancer, antiepileptic, antidiabetic, cardiovascular, anti-fertility, hepatoprotective, antimicrobial, anti-urolithiatic, and anti-asthmatic. Proteomics and genomics studies confirm the healing abilities of the plant, using various bioactive compounds, such as the glucosinolates, isothiocyanates, alkaloids, nitrile glycosides, polyphenols and vitamins, calcium, magnesium, amino acids and other nutrients and phytochemicals. Conclusion: Moringa has abundant phytochemicals/nutrients/biocompounds/vitamins/amino acids, in the leaves, stem, pods, seed, bark and stem, that are beneficial to children, women and men of all ages. It can be made powder, capsules, soups, and syrups and used for treating cancer, diabetes, and other diseases.
\end{abstract}

Key words: Moringa oleifera, Phytocompounds, Proteomic studies, Heat shock proteins, Phytochemicals, Bioactive compounds.

\section{INTRODUCTION}

Bogar, one of the greatest sithars of Tamil Nadu, South India, has explained the exceptional benefits Moringa root bark for its various uses. In his book, Bogar Yaelaeiram $^{1}$ in verses, 6847 to 6852 , the immense benefits of consuming it as a medicine is described in detail. The juice extracts of Moringa roots cooked in a special way, to make capsules of it and taken with honey, makes the body strong and fit, thus rejuvenating the body, to become active and enhance virility, even at old age. The nervous system becomes extremely strong. Even people suffering from nerve damage and muscle loss will become healthy with strong nerves and healthy muscle mass. The overall lifespan increases with great strength and appearance. He also mentions about Moringa soup (Murangai rasam), for energy, health, nutrition and other benefits. ${ }^{2}$ The warm soup, with pure cow ghee floating on the top, is prepared by adding a pinch of rock salt, onion, Haritaki (kadukkai); it is a refreshing and nourishing energy drink that is used frequently in the diet. He says that Moringa makes bones as strong as iron. Living in Pothigai hills, so richly fertile, he has studied about over 400 plants in detail and he finds Moringa to be a very rare plant, due to its great benefits. Knowing its values, he indicates that the amazing benefits of Moringa cannot be described by words.
Submission Date: 30-09-2020; Revision Date: 04-01-2021; Accepted Date: 30-04-2021

DOI: 10.5530/ijper.55.2s.105 Correspondence: Prof. Raji Sundararajan School of Engineering Technology, Purdue University, Rm 187, Knoy hall of Technology, West Lafayette, IN 47907, USA

Phone no: +1-7654946912 Email id: raji@purdue.edu

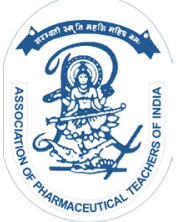

www.ijper.org 
Theraiyaar, another greatest sithar also has sung poems on Moringa's great qualities. He also indicates that the use of Moringa enhances the virility of men at any age and it is suitable for both men and women.

Thus, Moringa has proven to be both food and medicine for the general wellness of human race for generations and its numerous healthy and natural properties have also been studied and reported in a number of latest studies. ${ }^{3-10}$ This "miracle plant", a popular herbal and vegetable plant, available in different parts of the globe is known by several names, such as drumstick and horseradish. The species Moringa is known to emerge as: Plantea, Magnoliphyta, Magnoliopsida, Brassicales and Moringaceae, as in the order of botanical classification: kingdom, division, class, order, family and genus respectively. The genus from which Moringa is found to have 13 species. ${ }^{11}$

Moringa is a perennial plant that growths rapidly; it can grow in excess of $10 \mathrm{~m}$ in height and $20-40 \mathrm{~cm}$ in diameter. It is considered as a small to medium kind of tree size having a spirally arranged feather shaped leaves and low quality of timber. Bogar indicates that since all the strength and the nutrients are transferred to the leaves, pods, flowers, roots and barks, the timber is not as strong as other tress, but it can grow easily anywhere, by planting just a piece of the stem. ${ }^{2}$ This correlates with that of the Johns Hopkins Researcher, Fahey. ${ }^{3}$ He indicates that Moringa is a perennial softwood tree with low quality timber. The tree is soft and slender, stems with branch out once it reaches at least $1.5 \mathrm{~m}$. The flowers are of whitish or cream colour with some yellow dot at the base and the seeds are usually black or brown colour which can grow within weeks after planting if viable.

\section{Salient medicinal and Nutritional Characteristics}

From time immemorial and with today's various researches, Moringa has been considered as a power house of important nutritional contents and natural bioactive constitutes that makes every part of it is consumable as vegetables ${ }^{3,12}$ and is useful in treating various diseases, where it earned the name 'Miracle tree' as a result of its healing potency. $3,7,13,14$

Due to its various benefits and advantages, it is considered as one of the "most nutrient-rich plant yet discovered". All parts of the tree (Figure 1) leaves, flowers, pods (drumsticks), stem, seeds, roots, bark, gum and oil (from seeds) useful in numerous ways.

The diverse medicinal traditional usage of the Moringa plant are confirmed by latest scientific research, which reports the plant to contain large amount of essential nutrients including amino acids, vitamins, beta-carotenes, minerals and omega 3 and 6 fatty acids. ${ }^{3,14}$ In a 2019

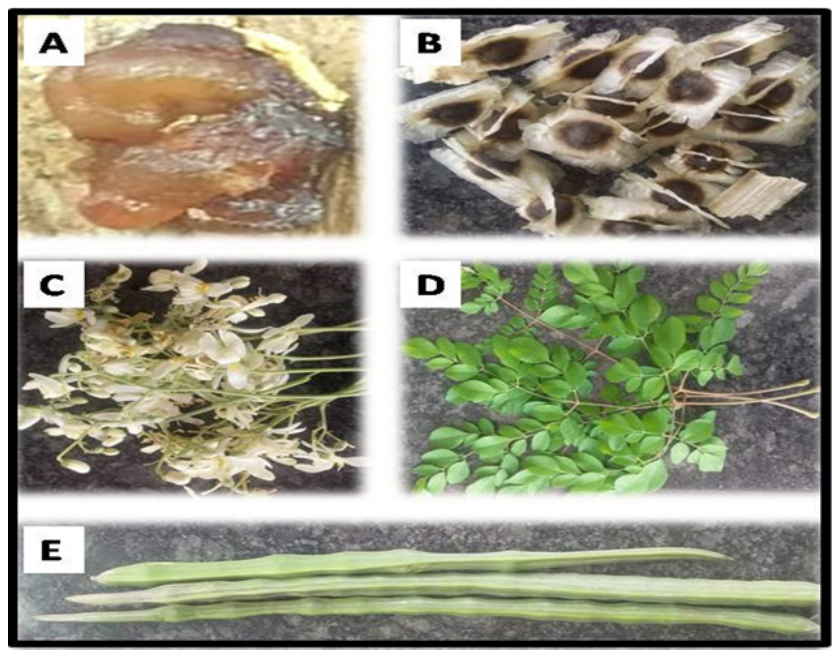

Figure 1: Various parts of Moringa i (A) Resin (B) Seeds (C) Flowers (D) Leaves (E) Pods used as nutraceuticals.

Genomics study, the transcriptome was deciphered by purifying and sequencing RNA from leaves, flower, stem, root and seed of Moringa tree, grown in Bengaluru. The sequencing data was analysed using both computational algorithms (Bioinformatics) and wet lab techniques. Out of a total 17000 transcripts, salient 36 candidate genes were identified from all these five tissues and their various medicinal and nutritional aspects were reported. They are synthesizing enzymes for compounds, such as flavonoids, terpenoids, vitamins and alkaloids and transporter of minerals. Bioactive compounds, like Quercetin, which is effective in metabolic disorders and its synthesizing enzymes were found more in leaves and flowers. Anti-cancer agent, Kaempferol was found to be abundant in flowers. Seeds had more of Benzylamine, anti-microbial, agent. Roots had anticancer agents, Ursolic acid and Oleanolic acid products and synthesizing agents. Table 1 gives the details of these compounds and their properties.

It can be seen the many properties mentioned by Bogar ${ }^{1}$ are identified here. Every part of Moringa has been reported by the Tree for Life organization to comprise of essential nutrients in good proportion. ${ }^{14}$ The leaves are rich in high level of beta-carotene, potassium, vitamins - A, B, C and $\mathrm{E}$, copper $(\mathrm{Cu})$, phosphorus $(\mathrm{P})$, folic acid, a-tocopherol, iron (Fe), and nicotinic acid. The various antioxidants include carotenoids, ascorbic acid and polyphenols. Table 2 shows the comparison of Moringa leaves, both fresh and dry leaves, for gram to gram $^{13}$ with other fruits and vegetables to indicate how richer this plant is. It contains higher values of diverse nutrients compared to individual food products or vegetables. Table 3 shows vitamins and mineral contents of per $100 \mathrm{~g}$ of edible portion of fresh and dry leaves. ${ }^{14}$ 


\begin{tabular}{|c|c|c|}
\hline Part of the tree & Various properties & Various Nutrients \\
\hline Leaves & $\begin{array}{c}\text { Anti-diabetic } \\
\text { Anti-oxidative } \\
\text { Anti-obesity } \\
\text { Hypotensive } \\
\text { Anti-inflammatory } \\
\text { Hepatoprotective } \\
\text { Cardioprotective } \\
\text { Anti-microbial } \\
\text { Anti-cancer } \\
\text { Anti-analgesic } \\
\text { Anti-viral } \\
\text { Neuroprotective }\end{array}$ & $\begin{array}{l}\text { Vitamin A } \\
\text { Vitamin C } \\
\text { Vitamin E } \\
\text { Iron } \\
\text { Calcium } \\
\text { Zinc } \\
\text { Magnesium } \\
\text { Quercetin } \\
\text { Kempferol } \\
\text { Benzylamine }\end{array}$ \\
\hline Flower & $\begin{array}{c}\text { Anti-diabetic } \\
\text { Anti-oxidative } \\
\text { Anti-obesity } \\
\text { Anti-cancer } \\
\text { Anti-analgesic } \\
\text { Neuroprotective } \\
\text { Anti-inflammatory } \\
\text { Anti-microbial } \\
\text { Hepatoprotective } \\
\text { Hypotensive }\end{array}$ & $\begin{array}{l}\text { Vitamin E } \\
\text { Calcium } \\
\text { Quercetin } \\
\text { Kaempferol } \\
\text { Benzylamine }\end{array}$ \\
\hline Stem & $\begin{array}{c}\text { Anti-obesity } \\
\text { Anti-microbial } \\
\text { Cardioprotective } \\
\text { Anti-cholosterol }\end{array}$ & $\begin{array}{c}\text { Vitamin C } \\
\text { Iron } \\
\text { Calcium } \\
\text { Benzylamine }\end{array}$ \\
\hline Root & $\begin{array}{c}\text { Anti-cancer } \\
\text { Anti-aging } \\
\text { Anti-inflammatory } \\
\text { Anti-oxidative } \\
\text { Cardioprotective } \\
\text { Anti-cholesterol } \\
\text { Anti-obesity } \\
\text { Anti-microbial } \\
\text { Anti-viral }\end{array}$ & $\begin{array}{c}\text { Iron } \\
\text { Zinc } \\
\text { Ursolic acid } \\
\text { Oleanolic acid } \\
\text { Benzylamine }\end{array}$ \\
\hline Seed & $\begin{array}{l}\text { Cardioprotective } \\
\text { Anti-cholesterol } \\
\text { Anti-diabetic } \\
\text { Anti-obesity } \\
\text { Anti-microbial }\end{array}$ & $\begin{array}{c}\text { Vitamin C } \\
\text { Vitamin E } \\
\text { Calcium } \\
\text { Quercetin (pod) } \\
\text { Benzylamine }\end{array}$ \\
\hline
\end{tabular}

Also Optima of Africa Ltd. ${ }^{9}$ states that 25 gram of dry Moringa leaf powder administered to a child daily gives an enormous amount of nutrients, including proteins, calcium, and other. Results from Tanzania on the use of dry Moringa leaf powder as a supplement for 99 children, under age 2 to treat anaemia, ${ }^{10}$ indicate that children gained weight $(79.3 \%)$, had increased haemoglobin level $(62.1 \%)$, reduced illnesses $(55.2 \%)$, improved health $(44.8 \%)$, increased appetite $(24.1 \%)$, retain haemoglobin after illness (17.2\%) and were active (13.8\%). In addition, the dry powder form of Moringa leaves has been established to have greater amount of carbohydrates than soy flour and mushroom powder, which are used in formulating healthy vegetable soup powder. ${ }^{3,14}$

\begin{tabular}{|c|c|c|c|}
\hline Food/Vegetable & Nutrients & $\begin{array}{l}\text { Fresh } \\
\text { leaves }\end{array}$ & Dry Leaves \\
\hline Oranges & Vitamin C & 7 times & 3.5 times \\
\hline Carrots & Vitamin A & 4 times & 10 times \\
\hline Yogurt & Protein & 2 times & 9 times \\
\hline Banana & Potassium & 3 times & 15 times \\
\hline Milk & Calcium & 4 times & 17 times \\
\hline Spinach & Iron & - & 25 times \\
\hline
\end{tabular}

\begin{tabular}{|c|c|c|}
\hline $\begin{array}{l}\text { Vitamins and mineral } \\
\text { contents }\end{array}$ & Fresh leaves & Dry leaves \\
\hline Carotene $(\text { Vit. A })^{*}$ & $6.78 \mathrm{mg}$ & $18.9 \mathrm{mg}$ \\
\hline Thiamin (B1) & $0.06 \mathrm{mg}$ & $2.64 \mathrm{mg}$ \\
\hline Riboflavin (B2) & $0.05 \mathrm{mg}$ & $20.5 \mathrm{mg}$ \\
\hline Niacin (B3) & $0.8 \mathrm{mg}$ & $8.2 \mathrm{mg}$ \\
\hline Vitamin C & $220 \mathrm{mg}$ & $17.3 \mathrm{mg}$ \\
\hline Calcium & $440 \mathrm{mg}$ & $2,003 \mathrm{mg}$ \\
\hline Calories & $92 \mathrm{cal}$ & $205 \mathrm{cal}$ \\
\hline Carbohydrates & $12.5 \mathrm{~g}$ & $38.2 \mathrm{~g}$ \\
\hline Copper & $0.07 \mathrm{mg}$ & $0.57 \mathrm{mg}$ \\
\hline Fat & $1.70 \mathrm{~g}$ & $2.3 \mathrm{~g}$ \\
\hline Fiber & $0.90 \mathrm{~g}$ & $19.2 \mathrm{~g}$ \\
\hline Iron & $0.85 \mathrm{mg}$ & $28.2 \mathrm{mg}$ \\
\hline Magnesium & $42 \mathrm{mg}$ & $368 \mathrm{mg}$ \\
\hline Phosphorus & $70 \mathrm{mg}$ & $204 \mathrm{mg}$ \\
\hline Potassium & $259 \mathrm{mg}$ & $1,324 \mathrm{mg}$ \\
\hline Protein & $6.70 \mathrm{~g}$ & $27.1 \mathrm{~g}$ \\
\hline Zinc & $0.16 \mathrm{mg}$ & $3.29 \mathrm{mg}$ \\
\hline
\end{tabular}

The seeds of Moringa is known to produce oil, called, Moringa oil, which comprises of important nutrients, such as fatty acids, sterols, terpenoids, carotenoids, phenolics and saponins, having medicinal application and usefulness in food industry. ${ }^{15}$ The flowers are also a great source of protein and dietary fibre providing enough amino acids and ash respectively. Amino acids, such as lysine methionine and cysteine found in this plant, especially the pods and leaves make it practically an excellent food supplement., ${ }^{3,13-16}$ It is interesting to note that most vegetables once cooked loses their nutritional composition, but this is not so with Moringa, which in whatever condition (fresh, dried, cooked) still retains its nutrients. ${ }^{14}$ Table 4 shows the amino acid contents of Moringa ${ }^{14}$ and Tables $5^{16}$ and $6^{17}$ show 
the phytoconstituents present in the various parts of Moringa and the various chemical components present in Moringa leaf essential oil, respectively.

\section{Phytochemical Analysis of Moringa}

Phytochemical examination of Moringa reveals quite a large number of bioactive compounds present in the leaves, pods, flowers, root and seeds., ${ }^{3,11,16,18}$ One of the major group of phytocompound reported to be found in large quantity in almost all parts of the plant except the root is glucosinolates (GS) or its metabolized form isothiocyanates (ITS) (Figure 2), which is mainly made up of sugar and rhamnose.

From glucosinolates group, many compounds were identified, which showed diverse biological activities. These compounds include 4-( $\alpha$-L-rhamnopyranosyloxy) benzyl isothiocyanate (4RBITC) formed by hydrolysis of 4-( $\alpha$-L-rhamnopyranosyloxy)-benzyl glucosinolate (4RBGS), 4-( $\alpha$-L-glucopyranosyloxy)-benzylglucosinolate (4GBGS),4'-O-acetyl-4-( $\alpha$-L-rhamnopyranosyloxy)-

Table 4: Amino acid contents of Murungai. ${ }^{14}$

\begin{tabular}{|c|c|c|}
\hline Aminoacids & Fresh leaves & Dry leaves \\
\hline Arginine & $406.6 \mathrm{mg}$ & $1,325 \mathrm{mg}$ \\
\hline Histidine & $149.8 \mathrm{mg}$ & $613 \mathrm{mg}$ \\
\hline Isoleucine & $299.6 \mathrm{mg}$ & $825 \mathrm{mg}$ \\
\hline Leucine & $492.2 \mathrm{mg}$ & $1,950 \mathrm{mg}$ \\
\hline Lysine & $342.4 \mathrm{mg}$ & $1,325 \mathrm{mg}$ \\
\hline Methionine & $117.7 \mathrm{mg}$ & $350 \mathrm{mg}$ \\
\hline Phenylalinine & $310.3 \mathrm{mg}$ & $1,388 \mathrm{mg}$ \\
\hline Threonine & $117.7 \mathrm{mg}$ & $1,188 \mathrm{mg}$ \\
\hline
\end{tabular}

\section{Table 5: Phytoconstituents present in the various} parts of Moringa. ${ }^{8}$

\begin{tabular}{|c|c|}
\hline Part & Bioactive Compounds \\
\hline Leaves & $\begin{array}{c}\text { Gallic acid, chlorogenic acid, ellagic acid, ferullic acid, } \\
\text { flay 5 kaempherol glycosides, quercetin glycosides, } \\
\text { tutin syringic acid caffeoylquinic acid glycosides, } \\
\text { thiocarbomate, niazirin, niaziridin, niazirinin, benzyl } \\
\text { isoth---, niaziminin A, niaziminin, ascorbic acid, } \\
\text { carotenoids, } \beta \text {-sitoserol }\end{array}$ \\
\hline $\begin{array}{c}\text { Fruits/ } \\
\text { Pods }\end{array}$ & $\begin{array}{c}\text { Gallic acid chlorogenic acid, ellagic acid, ferullic acid } \\
\text { kaempherol, quercetin vanillin niazirin, niaziridin, } \\
\text { glactose, arabinose, rhamnose }\end{array}$ \\
\hline Roots & $\begin{array}{c}\text { Benzyl glucosionolate, niazimicin, aurentiamide } \\
\text { acetate 4, 1,3-dibenzylurea }\end{array}$ \\
\hline Seeds & $\begin{array}{c}\text { Benzyl isothiocyanate, moringyne, several amino } \\
\text { acids, sterols, tocopherol, fatty acid, niazimicin, } \\
\text { niazirin, } \beta \text {-sitosterol glycosides, glucomoringin }\end{array}$ \\
\hline Bark & Benzyl glucosinolate, niaziridin niazirin \\
\hline Flower & Octadecen, oleol, satol, deconoic acid. dodecanal \\
\hline
\end{tabular}

Table 6: Chemical components of Moringa leaf essential oil. ${ }^{17}$

\begin{tabular}{|c|} 
essential oil. ${ }^{17}$ \\
Components \\
Oxygenated monoterpenes \\
Linalool \\
$\alpha$-Terpineol \\
\hline Phenolic compounds \\
p-Vinylguaiacol \\
\hline Oxygenated Sesquiterpenes \\
Cis-Dihydrogarofuran \\
Eudesm-11-en-4- $\alpha$, $\alpha$-diol \\
\hline Hydrocarbons \\
1-Octadecene \\
Octadecane \\
5-Octadecin \\
n-Hexadecanol \\
Nonadecane \\
1-Eicosene \\
Eicosene \\
n-Octadecanol \\
Heneicosane \\
Cyclopentadecanol \\
1-Docosene \\
Docosane \\
Cis-9-Eicosen-1-ol \\
Tricosane \\
Tetracosane \\
Pentacosane \\
Hexacosane \\
Heptacosane \\
Octacosane \\
Nonacosane \\
Triacontane \\
Other \\
Hexenyl propanoate \\
Phenylethyl alcohol \\
Pseudo Phytol \\
\hline
\end{tabular}<smiles>[R]/C(=N/OS(=O)(=O)[O-])S[C@H]1O[C@H](CO)[C@@H](O)[C@H](O)[C@H]1O</smiles>

Glucosinolate

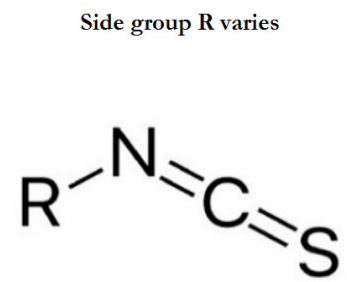

Isothiocvanate
Figure 2: Structure of Glucosinolate and its hydrolysed form Isothiocyanate.

benzylglucosinolate (the acetylated form of 4RBGS) and 4'-O-acetyl-4-( $\alpha$-L-glucopyranosyloxy)benzylglucosinolates (acetylated derivative of 4GBGS). ${ }^{19}$ Other compounds in this group found in Moringa include, 3'-O-acetyl- $\alpha$-L- rhamnosyloxybenzyl ITC,4(2'-O-acetyl- $\alpha$-L-rhamnosyloxy)benzyl ITC, benzyl glucosinolates, 2 '- $O$-acetyl- $\alpha$-L-rhamnosyloxybenzyl ITC,4-hydroxybenzyl glucosinolates (sinalbin), 4'-O-acetyl- 
$\alpha$-L-rhamnosyloxybenzyl ITC., ${ }^{3,15}$ The leaves, flowers, pods, stem and seeds of Murungai have been reported to contain the most amounts of 4RBGS also called glucomoringin, while benzyl glucosinolate also known as glucotropaeolin is found predominantly in the root part. In general the highest amount of glucosinolate is in the stem and leaf parts. ${ }^{15}$

Also, the leaf part of Moringa is revealed to contain large amount of polyphenols comprising of flavonoids and phenols and help to protect against diseases mainly related to oxidative stress. Major flavonoids with enormous therapeutic potentials in it are Quercetin, myrecytin and kaempferol. ${ }^{7,14}$ These flavonoids are also found in other parts of the plant except in the seeds and roots. ${ }^{11}$ Gallic acid and chlorogenic acid are some of the phenolic compounds found in the dry leaves. The leaves have also been studied to be a good source of saponins and tannins. ${ }^{20}$ In addition, studies showed that the bark of Moringa plant contains moringine and moringinine both of each are alkaloids, gum extracted from Moringa contains L form of arabinose, xylose, galactose, glucuronic acid and rhamnose, also sucrose, amino acids and D-glucose are found in flower. Furthermore, carotenoids especially E-lutein in large amount, have also been reported to be found in the flowers and immature pods of Moringa. ${ }^{11}$

\section{Proteomics studies of Moringa}

Protein profiles of Moringa leaves, stem, bark and root were studied by Wang et al. using mass spectroscopy and bioinformatics methods. ${ }^{4}$ There were 101 proteins from leaves, 51 from stem, 94 from bark and 67 from root, out of total 202 proteins. Only 5 were common for all the four parts. Table 7 shows the $\%$ of various functional categories of proteins of these parts. Of all the proteins, catalytic activity was the most abundant in all these four parts. It was $46.54 \%$ in leaves, $55.3 \% 2$ in bark, $42.31 \%$ in stem and $57.35 \%$ in root. Binding protein was the $2^{\text {nd }}$ most abundant proteins; they are $10.89 \%$ in leaves, $9.58 \%$ in bark, $15.38 \%$ in stem and $5.88 \%$ in root. While leaves and stem have exactly the same 9 functional categories, while bark has 7 common ones, out of total 8 . The $8^{\text {th }}$ protein in this was biological process localization, which was common to the root, along with other 7 ones in common with bark. It shares 8 processes with stem and leaves. The new ones are antioxidant activity and biological process localization.

Out of these, there were a number of heat shock proteins (Hsp). Hsps are chaperone proteins that protect the plant from stresses, such as heat. They regulate the folding and accumulation of proteins, in addition to localization and degradation in all plants and animals.
Table 7: Functional categories of proteins in Murungai leaves, bark, stem and root. ${ }^{4}$

\begin{tabular}{|c|c|c|c|c|}
\hline Process & Leaves & Bark & Stem & Root \\
\hline \multicolumn{4}{|l|}{ Molecular Function } \\
\hline Catalytic activity & $46.54 \%$ & $55.32 \%$ & $42.31 \%$ & $57.35 \%$ \\
\hline Binding & $10.89 \%$ & $9.58 \%$ & $15.38 \%$ & $5.88 \%$ \\
\hline $\begin{array}{c}\text { Structural molecular } \\
\text { activity }\end{array}$ & $1.98 \%$ & $2.13 \%$ & $3.85 \%$ & $5.88 \%$ \\
\hline Antioxidant activity & - & - & - & $1.47 \%$ \\
\hline Biological process & & & & \\
\hline $\begin{array}{c}\text { Cellular process } \\
\text { Metabolic process }\end{array}$ & $10.89 \%$ & $6.38 \%$ & $13.46 \%$ & $1.47 \%$ \\
\hline $\begin{array}{c}\text { Immune system } \\
\text { process }\end{array}$ & $0.99 \%$ & $3.19 \%$ & $3.85 \%$ & $2.94 \%$ \\
\hline $\begin{array}{c}\text { Biological process } \\
\text { localization }\end{array}$ & - & $1.06 \%$ & - & $1.47 \%$ \\
\hline $\begin{array}{c}\text { Cellular } \\
\text { component }\end{array}$ & & $1.85 \%$ & $13.25 \%$ \\
\hline $\begin{array}{c}\text { Macromolecular } \\
\text { complex }\end{array}$ & $17.82 \%$ & $13.83 \%$ & $11.53 \%$ & $1.47 \%$ \\
\hline $\begin{array}{c}\text { Cytoskeleton } \\
\text { Organelle }\end{array}$ & $0.99 \%$ & $1.06 \%$ & $1.92 \%$ & $5.88 \%$ \\
\hline & $5.94 \%$ & - & $3.85 \%$ & $1.47 \%$ \\
\hline
\end{tabular}

\begin{tabular}{|c|c|}
\hline Part & Heat shock proteins \\
\hline Leaves & $\begin{array}{c}\text { Hsp 70, Hsp 70-7, Hsp 70-15, Hsp 80, } \\
\text { Hsp } 90 \text { and Hsp STI }\end{array}$ \\
\hline Stem & Hsp 90, Hsp 82 \\
\hline Bark & Hsp 70, Hsp 60-2, Hsp 81, Hsp 83 \\
\hline Root & Hsp 70, Hsp 80, Hsp 90, Hsp STI \\
\hline
\end{tabular}

These group of proteins are induced whenever the plants undergo any stresses. ${ }^{21}$ The induction of these proteins are a common occurrence in all living beings, including humans (Homo sapiens). The Hsps are named as Hsp 90, Hsp 70, and so on, where the numbers indicate the molecular weights, in $\mathrm{kDa}$. For example, Hsp 90 means its molecular weight is $90 \mathrm{kDa}$, Hsp 70 means its molecular weight is $70 \mathrm{kDa}$. Hsp 90, Hsp 70, and Hsp 60 are some of the most common Hsps occurring in various plants and they are also seen in Moringa. These diversification of Hsp proteins indicate the adaptation of the plant, both morphologically and physiologically, to various stresses, both external and internal. Table 8 shows the various Hsp proteins in the leaves, bark, stem and root of Moringa. ${ }^{4}$

Similar heat shock proteins are available in humans too. Figure 3 shows the interaction protein diagram of Hsp 70 (HSPA2), a $70 \mathrm{kDa}$ protein with top 5 proteins. ${ }^{22} \mathrm{It}$ 


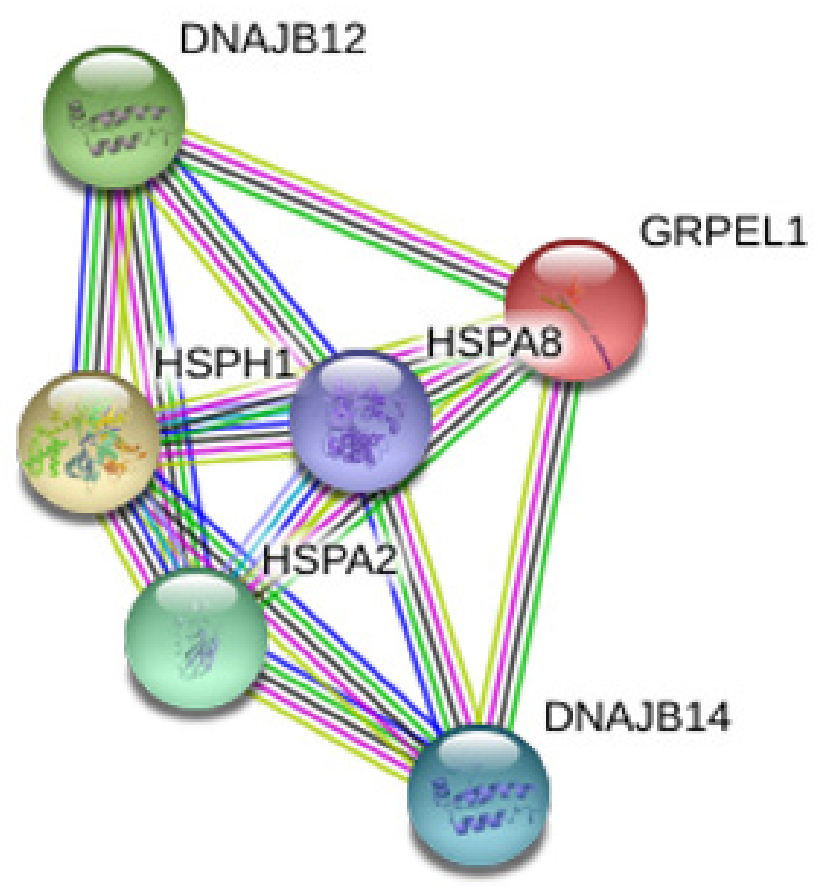

Figure 3: Top 5 Interacting proteins of Hsp70.

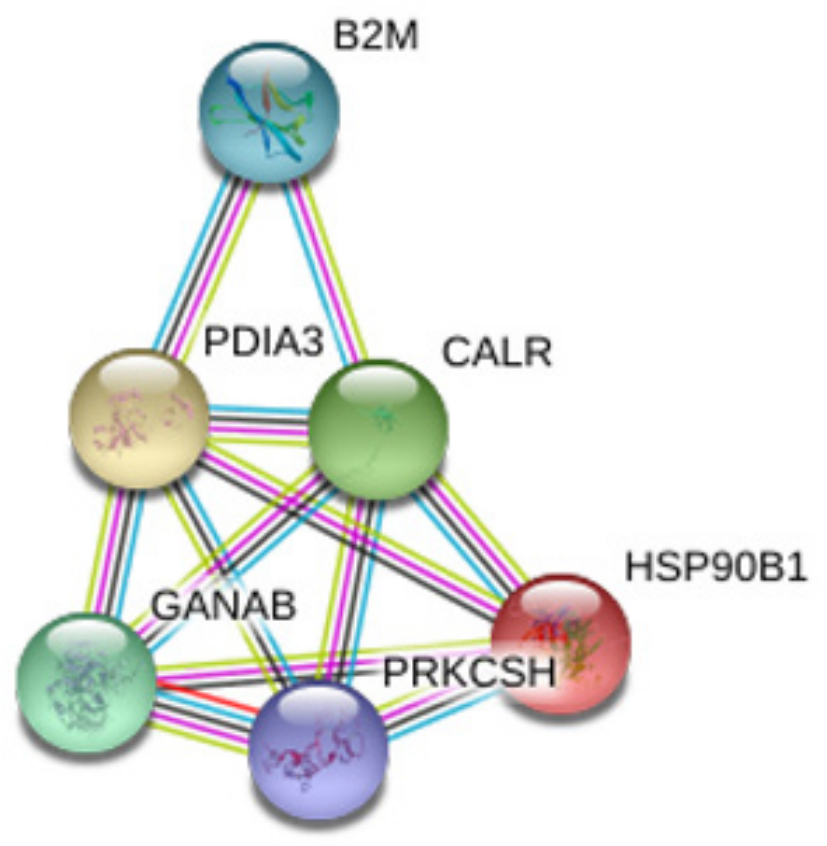

Figure 4: Top 5 Interacting proteins of Calreticulin (CALR).

interacts with HSPH1, HSPAB, DNAJB14, DNAJB12 and GRPEL1 proteins. Hsp 70 group of proteins in humans is reported to be in the cellular locations of cytosol, nucleus, mitochondria and endoplasmic reticulum, performing the functions of protein folding, cytoprotection, molecular chaperones, just like in Moringa.

Another protein, predicted based on Swiss Protein data base is Calreticulin (6). It was identified using the extract

\begin{tabular}{|c|c|}
\hline Enrichment GO terms & KEGG pathways \\
\hline Hydrolase activity & Energy metabolism \\
\hline Oxidoreductase activity & Carbohydrate metabolism \\
\hline Structural molecule activity & Amino acid metabolism \\
\hline Transferase activity & $\begin{array}{l}\text { Carbon fixation in } \\
\text { photosynthetic organisms }\end{array}$ \\
\hline Enzyme regulator activity & $\begin{array}{c}\text { Glyoxylate and dicarboxylate } \\
\text { metabolism }\end{array}$ \\
\hline Antioxidant activity & $\begin{array}{l}\text { Protein processing in } \\
\text { endoplasmic reticulum }\end{array}$ \\
\hline Molecular transducer activity & Glycolysis/gluconeogenesis \\
\hline $\begin{array}{c}\text { Organic substance metabolic } \\
\text { process }\end{array}$ & $\begin{array}{l}\text { Glycine, serine and } \\
\text { threonine metabolism }\end{array}$ \\
\hline Cellular metabolic process & Oxidative phosphorylation \\
\hline Response to stress & $\begin{array}{l}\text { Alanine, aspartate and } \\
\text { glutamate metabolism }\end{array}$ \\
\hline Biosynthetic process & $\begin{array}{c}\text { Cysteine and methionine } \\
\text { metabolism }\end{array}$ \\
\hline $\begin{array}{l}\text { Single-organism metabolic } \\
\text { process }\end{array}$ & Arginine biosynthesis \\
\hline Intracellular part & $\begin{array}{l}\text { Valine, leucine and } \\
\text { isoleucine degradation }\end{array}$ \\
\hline Cytoplasm & - \\
\hline $\begin{array}{l}\text { Intracellular membrane-bounded } \\
\text { organelle }\end{array}$ & - \\
\hline Plasma membrane & - \\
\hline
\end{tabular}

of Moringa leaves. Calreticulin (CALR) is another highly conserved chaperone protein, which resides primarily in the endoplasmic reticulum and is involved in a variety of cellular processes, such as cell adhesion. Additionally, it functions in protein folding quality control and calcium homeostasis. Calreticulin is also found in the nucleus. Figure 4 shows the interaction diagram with Top 5 proteins. $^{23}$

In another study ${ }^{5}$ by Shi et al., 3348 proteins were identified using Moringa leaf extract. The various molecular function and biological processes include hydrolytic activity (676 proteins) and organic substance metabolism (2382 proteins). They found 548 oxidoreductases, 524 transferases, 190 structural and molecularly active proteins and 20 proteins with molecular transduction activity. The extract contained a mixture of several hydrolytic enzymes, in which proteases as the key enzymes are responsible for the observed milk-clotting activity. KEGG analyses indicate energy metabolism, carbohydrate metabolism, protein metabolism and other pathways. Table 9 shows the enrichment GO terms and KEGG pathways identified in this study. 


\section{CONCLUSION}

While today's big pharma firms are hardly 100 years old and are reinventing the wheel for new drug compounds, for many 100s or 1000s of years, sithars and others have been using natural medicinal and nutritional plants, such as Moringa for the benefit of humankind. As illustrated by various studies, there are abundant hytochemicals/ nutrients/biocompounds/vitamins/amino acids, in the leaves, stem, pods, seed, bark and stem of Moringa that are beneficial to children, women and men of all ages. It can be made powder, capsules, and syrups and used for the various diseases. It is worthwhile to use these for cancer cure and other diseases, because they have no or least side effects, no or least toxicity and excellent cost/ benefit ratio. Today's proteomics and genomics studies unravel multipurpose, multiple proteins and genes and open the gateway for better treatments and clinical trials on these are urgent to meet the unmet needs of cancer and many other chronic diseases, including diabetes. Future work should also gear towards the in-depth understanding and scrutiny of the pharmacological activities and mode of actions of Moringa.

\section{CONFLICT OF INTEREST}

The authors declare that there is no conflict of interest.

\section{REFERENCES}

1. Murungai Ver Marunthu - With English Subtitles - Bogar 7000 - Lakslead YouTube. 2000. [cited 2020 Dec 3]. Available from: https://www.youtube.com/ watch?v=q7Z1tDFPC1k\&ab_channel=LAKSLEAD

2. Soundarrajan I. Vikatan A. Iraiyuthir kaadu: Indra Soundarrajan series Ananda Vikatan. 2019. [cited 2020 Dec 3]. Available from: https://www. vikatan.com/spiritual/literature/152014-iraiyuthir-kaadu-indra-soundarrajanseries

3. Fahey J. Moringa oleifera: A Review of the Medical Evidence for its Nutritional, Therapeutic, and Prophylactic Properties. Part 1. Trees Life J. 2005;1(5).

4. Wang L, Zou Q, Wang J, Zhang J, Liu Z, Chen X. Proteomic Profiles Reveal the Function of Different Vegetative Tissues of Moringa oleifera. Protein J. 2016;35(6):440-7.

5. Shi Y, Prabakusuma AS, Zhao Q, Wang X, Huang A. Proteomic analysis of Moringa oleifera Lam. leaf extract provides insights into milk-clotting proteases. LWT. 2019;109:289-95. Available from: http://www.sciencedirect. com/science/article/pii/S0023643819303391

6. Wahyuni A, Masyitoh F. Molecular mechanism prediction of protein from Moringa oleifera leaves using computational approach. Int J Adv Life Sci Res. 2018;1:28-33.
7. National Centre for Biological Sciences. Genomics uncovers the mystery of the magic drumstick tree - Moringa oleifera. 2019. [cited 2020 Dec 3]; Available from: https://phys.org/news/2019-05-genomics-uncovers-mysterymagic-drumstick.html

8. Singh A, Dayal R, Ojha RP, Mishra KP. Promising Role of Moringa oleifera (Lam.) In Improving Radiotherapy: An Overview. J Innovations Pharm Biol Sci. 2015;2:182-92.

9. Creighton W. Optima of Africa Limited. Moringa oleifera seed production in Tanzania. Agritrop. 2001. [cited 2020 Dec 3]. Available from: https://agritrop. cirad.fr/511722/

10. Shija A, Rumisha S, Oriyo N, Kilima S, Massaga J. Effect of Moringa oleifera leaf powder supplementation on reducing anemia in children below two years in Kisarawe District, Tanzania. Food Sci Nutr. 2019;7(8):2584-94.

11. Saini RK, Sivanesan I, Keum YS. Phytochemicals of Moringa oleifera: A review of their nutritional, therapeutic and industrial significance. 3 Biotech. 2016;6(2):203. Available from: https://pubmed.ncbi.nlm.nih.gov/28330275

12. Sultana B, Anwar F. Flavonols (kaempeferol, quercetin, myricetin) contents of selected fruits, vegetables and medicinal plants. Food Chem. 2008;108(3):879-84.

13. Mahmood KT, Mugal T, Haq IU. Moringa oleifera: A natural gift-a review. J Pharm Sci Res. 2010;2(11):775-81.

14. The Magical Moringa by: Vanita Agarwal. California College of Ayurveda. Year??? [cited 2020 Dec 3]. Available from: https://www.ayurvedacollege. com/blog/magicalmoringa/

15. Amaglo NK, Bennett RN, Curto RBL, Rosa EAS, Turco VL, Giuffrida A, et al. Profiling selected phytochemicals and nutrients in different tissues of the multipurpose tree Moringa oleifera L., grown in Ghana. Food Chem. 2010;122(4):1047-54. Available from: http://www.sciencedirect.com/science/ article/pii/S0308814610003663

16. Anwar F, Latif S, Ashraf M, Gilani AH. Moringa oleifera: A food plant with multiple medicinal uses. Phytother Res. 2007;21(1):17-25.

17. Marrufo T, Nazzaro F, Mancini E, Fratianni F, Coppola R, Martino LD, et al. Chemical composition and biological activity of the essential oil from leaves of Moringa oleifera Lam. cultivated in Mozambique. Molecules. 2013;18(9):10989-1000. Available from: https://pubmed.ncbi.nlm.nih. gov/24022760

18. Senthilkumar A, Karuvantevida N, Rastrelli L, Kurup SS, Cheruth AJ. Traditional Uses, Pharmacological Efficacy, and Phytochemistry of Moringa peregrina (Forssk.) Fiori.: A Review. Frontiers in Pharmacology. 2018;9:465. Available from: https://www.frontiersin.org/article/10.3389/fphar.2018.00465

19. Chodur GM, Olson ME, Wade KL, Stephenson KK, Nouman W, Garima, et al. Wild and domesticated Moringa oleifera differ in taste, glucosinolate composition, and antioxidant potential, but not myrosinase activity or protein content. Sci Rep. 2018;8(1):7995. Available from: https://doi.org/10.1038/ s41598-018-26059-3

20. Almatrafi MM, Vergara-Jimenez M, Murillo AG, Norris GH, Blesso CN, Fernandez ML. Moringa Leaves Prevent Hepatic Lipid Accumulation and Inflammation in Guinea Pigs by Reducing the Expression of Genes Involved in Lipid Metabolism. Int J Mol Sci. 2017;18(7):1330.

21. Al-Whaibi MH. Plant heat-shock proteins: A mini review. J King Saud UnivSci. 2011;23(2):139-50. Available from: http://www.sciencedirect.com/ science/article/pii/S101836471000087X

22. HSPA2 Gene - Gene Cards, HSP72 Protein, HSP72 Antibody. [cited 2020 Dec 3]. Available from: https://www.genecards.org/cgi-bin/carddisp. pl?gene=HSPA2

23. CALR Gene - Gene Cards, CALR Protein, CALR Antibody. 2020. [cited 2020 Dec 3]. Available from: https://www.genecards.org/cgi-bin/carddisp. pl?gene $=$ CALR 


\section{PICTORIAL ABSTRACT}

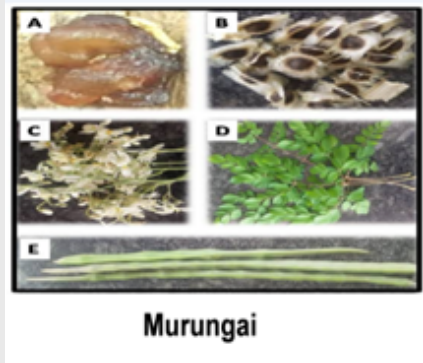

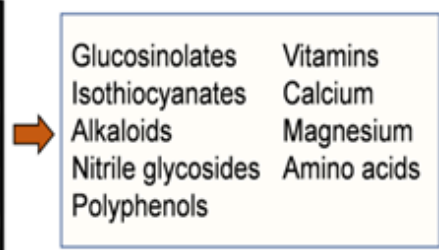

Phytochemicals and nutrients present in Murungai

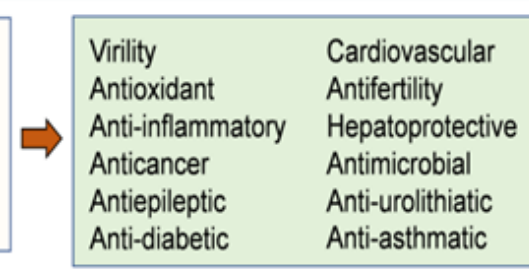

Biological and pharmacological activities of Murungai

\section{About Authors}

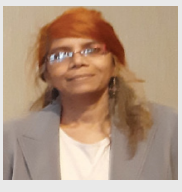

Raji Sundararajan is Professor at the School of Engineering Technology, Purdue University. She was the recipient of the 2010 Indiana 'Women \& Hi-Tech' award for 'Distinguished use of technology in healthcare Life Science' and won a prestigious, one- year (2010/11) fellowship to study regenerative medicine therapy using optoinjection and electroporation techniques at Purdue. She is an Associate Editor for IEEE Access and IEEE DEI transactions and a reviewer of NIH, NSF, and others' proposals, and various scholarly journals.

Cadet Love Mendie is a research scholar in the School of Life Sciences, BS Abdur Rahman Crescent Institute of Science and Technology, Chennai, India. Her research interests include phytomedicine, antibiotic resisatnce and related.

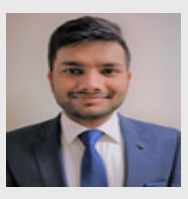

Lakshya Mittal earned his Ph.D. from School of Engineering Technology, Purdue University. He received his M.S. degree in Electrical Engineering in 2013 from the Indian Institute of Technology, Madras (IITM) in 2015 and subsequently worked as a Post Graduate Engineer Trainee at ALSTOM Transport India Ltd. until 2016. His current project is Electrochemotherapy for aggressive forms of breast cancer. He is also interested in looking at protein profile after the Electrochemotherapy treatment on the breast cancer. Currently he is employed in a biotech company.

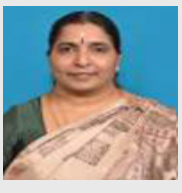

Gowrisree V received her Doctorate in High Voltage Engineering in 2008 from the College of Engineering, Guindy, Anna University India. She is presently an Associate Professor in the Department of Electrical and Electronics Engineering, College of Engineering, Guindy, Anna University, India, with over 25 years of teaching experience. Her current research topics are application of high voltage engineering for cancer treatment and other applications. She is also interested in water processing and preservation of liquid foods by pulsed electric fields. She also has extensive experience in testing of high voltage power apparatus. Her area of research also includes extraction of carotenoids rich in antioxidants like tomatoes, papaya, watermelon and carrots by pulse electric fields.

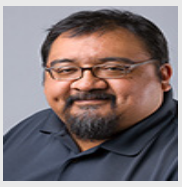

Ignacio Camarillo received a B.A. in Biology from St. Mary's College and his Ph.D in Physiology from Wayne State University, Detriot, MI, and is an Associate Professor faculty at Purdue University, W. Lafayette, IN in the Department of Biological Sciences. His research interests focus on defining the influence of diet and obesity on breast cancer progression, understanding the mechanisms of diet and exercise in breast development and breast cancer prevention, and defining novel physical techniques for enhancing drug delivery.

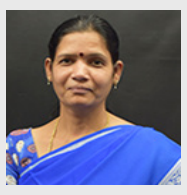

Hemalatha Srinivasan is the Dean of School of Life Sciences, BS Abdur Rahman Crescent Institute of Science and Technology, Chennai, India. She has 21 years of experience in research and has published over 100 papers. Her research areas include Functional genomics, nanotechnology, bioinformatics, molecular pathology, phytomedicine and antibiotic resistance.

Cite this article: Sundararajan R, Mendie EL, Mittal L, Varadarajan GS, Camarillo IG, Srinivasan H, Sundararajan R. Medicinal and Nutritional Wonders of Miracle Moringa oleifera Lam.: Another Look. Indian J of Pharmaceutical Education and Research. 2021;55(2s):s345-s352. 